\title{
A Study on Students' Attitude Towards BBA Program at Janapriya Multiple Campus
}

\section{Amin Palikhe ${ }^{* *}$ and Nabin Bahadur Adhikari*}

Under the study on the students' attitude towards BBA program at JMC is to study of macro level perspective of BBA program. This research article is based on primary and secondary data including 153 sampling and purposive with descriptive research designs. This program is student centered so that students' participation is important to achieve the objective of the program. This study shows that political situation including environmental factors is major role to play for the effectiveness of $B B A$ program. This is competitive program, immediately applicable, not use for every social group even though it is learn for being a good businessman, entrepreneur and development, being a middle level manager in the competitive world by using creative mind of the students. Need and use of different pedagogies, language efficiency and use and problems regarding to program and campus's perception are disclosed in here.

Key Words: active learning cooperative, BBA program, effectiveness, JMC, program, students learning center, team work

\section{Introduction}

The four years BBA program is tailored made to serve the needs of the bright young persons who have completed twelve years of education and are looking for a career education in entrepreneurship, management profession or towards higher education in business administration. This program is open to the students with diverse educational backgrounds including, humanities, science, arts and commerce. However, being a program with challenging curricula and contents, it is accessible mainly to those students who have excellent academic record and high potential for success.

The Bachelor of Business Administration (BBA) program aims to create a new generation of business leaders that would have an active role in their communities and contribute to the management of the technology driven economies world. The program focuses on developing knowledge and skills in core areas of management applicable to manufacturing and service industries. The curriculum is designed to equip the students with the competencies and attitudes needed for success in the local and global workplace. It also provides the students with a unique learning experience where they can acquire different skills that help them adapt to a continuously evolving business environment. It enables students to develop and demonstrate competencies in effective communication, application of qualitative and quantitative analysis, problem solving, 
decision-making, critical thinking, entrepreneurship, team work and leadership. Therefor the vision and mission is to be contributed to the sustainable economic and social developments of world by developing innovative, highly qualified, and socially responsible leaders. To accomplish this mission, program focus on critical thinking, innovation, and entrepreneurial spirit as a way of life among our students and faculty, create and promote a research-friendly environment for faculty and students in different business related areas, foster and nurture research and teaching collaborations with business schools and with the local, regional, and international business community, select students from among the best, that are motivated, committed and have high aspirations, and strong leadership potential and provide a state of the art learning environment equipped with the cutting-edge technologies and backed by up-to-date teaching methodologies. For the support of vision and mission, faculty should be committed to core values that promote; excellence, ethics and integrity, diversity, freedom of thought and expression and respect for the individual (http://www.hec. gov.pk).

Similarly, to achieve the objective of BBA program, teachers' effectiveness and effort, students' attitude, available environmental situation are important to judge and analyses the effectiveness of the BBA program. The role of teacher preparation is as a key to effectiveness. Effective teachers understand and apply knowledge of students to motivate and engage them and develop a positive climate in the classroom in order to make it a stimulating learning environment. Regarding the 'how to teach,' or pedagogical preparation, subject specific methods courses in education have a positive impact. The report concludes "the pedagogical aspects of teacher preparation matter, both for their effects on teaching practice and for their ultimate impact on student achievement (http.www.ncate.org).

Upon successful completion of the BBA program, each student will be able to articulate a foundation of knowledge and skills that supports and facilitates lifelong learning and professional development, communicate effectively and professionally and demonstrate the ability to identify and evaluate relevant information for decision-making and make usage of diagnostic thinking skills and analytical techniques to assess the information and solve problems in the environment, understand the importance of teamwork and group dynamics and to work effectively in teams, understand various leadership styles and exercising these styles according to the requirement of the situation, understand the dynamics of the organizational conflict and power and politics and make use of their analytical and interpersonal skills accordingly acquire awareness of global diverse perspectives and understand the theory, operations, and challenges of global business, demonstrate effectively practicing of overall functional business knowledge and ability to identify and interpret essential business concepts, principles and skills, identify core organizational values and understand the issues of ethical and social diversity based on ethic, gender, religion, and culture and demonstrate the ability to propose feasible solutions to these issues, understand computer-based information systems and able to use end-user computing tools and infrastructures to apply and interpret functional business knowledge, integrate business disciplines in order to develop competitive 
perspectives of local and global business dynamics, understand and analyze the legal and ethical implications of business decisions, demonstrate effective leadership, entrepreneurship skills and individual and group dynamics.

Janapriya Multiple Campus (JMC) was established in 2048 (1990) in participation of local community including social workers, teachers, educationists, academics and social organizations. Shreejana development Centre (SDC) and Janapriya Higher Secondary School (JHS) are the local organizations to establish the campus. Hundreds of meetings and interaction were held at SDC and JHS with the community people in activation of SDC and the academics. Continued meetings and interaction materialized to establish a community campus in this region. As a result, JMC came into existence. BBA program has been launched in JMC since 2003. The mission of BBA is to develop socially responsive, creative and result-oriented management professionals to fulfill the middle level managerial positioners in the rapidly growing business sectors in Nepal and abroad. So this study focuses on the attitude of students regarding the program, environment and infrastructure in the college as expected by the program. Therefore the main problems are - what is the attitude towards the BBA program? Where the program is only measured by teachers' effectiveness and effort used in teaching pedagogies? What sort of environment and infrastructures are required for effective learning of BBA program?

Therefore, this study analyze the attitude towards BBA program at JMC that helps to achieve the vision, mission and goal of the program and campus as well as study further analyze the micro level objectives including teacher's effort and effectiveness regarding to use of pedagogies, identify the behavior of the students regarding this program, and insure the requirement environment for effectiveness of BBA program.

\section{Data and Method}

To conduct the research, purposive with descriptive and analytical research methodology has been adopted in Janapriya Multiple Campus at Simalchour in Pokhara (JMC). Both the primary and secondary sources for data collection are used in this research. All total 153 samples were taken from the third, fifth and seven semester's students from the odd semester in JMC. This study has used closed-ended and scaling questionnaire as part of data collection procedure. Such type of questions are used to generate statistics in quantitative form from the qualitative dimensions. As these follow a fixed format, so most of the responses can be entered easily into a computer for ease of analysis, and frequencies can be easily tabulated. For the social ethic, respondents' consent is developed and editing, data processing and analysis procedure are used by statistical tool 'SPSS'.

\section{Results and Discussion}

Except the theoretical outcomes of the BBA program, table 1 show the research base outcomes of the BBA program whether the program is effective on the basis of students' 
Janapriya Journal of Interdisciplinary Studies, Vol. 2, No.1 (December 2013)

attitude towards the program, infrastructure available in the college periphery and environmental situation. All the responses in total are particular important determinant or factor that affect in the effectiveness of BBA program and given the percentage in parenthesis as "Yes" and rest of the percentage is "No" responses.

Table 1

Response and Percentage of Important Determinants of effectiveness of learning center BBA Program

\begin{tabular}{|l|l|l|}
\hline Determinants: & $\begin{array}{l}\text { Yes Responses } \\
\text { (Percent) }\end{array}$ & $\begin{array}{l}\text { No Responses } \\
\text { (Percent) }\end{array}$ \\
\hline Requirement of Coordination and Communication & $149(97.4)$ & $4(2.6)$ \\
\hline Environment Influence in the Outcomes of Program & $54(35.3)$ & $99(64.7)$ \\
\hline Requirement of Political Involvement & $15(9.8)$ & $138(90.2)$ \\
\hline Active Learning Program & $151(98.7)$ & $2(1.3)$ \\
\hline Useful for All Social Classes Students & $55(33.9)$ & $98(64.1)$ \\
\hline Expensive in Terms of Time and Cost & $102(66.7)$ & $51(33.3)$ \\
\hline Makes Middle Level Manager & $133(86.9)$ & $20(13.1)$ \\
\hline $\begin{array}{l}\text { Learn to Effective in the Present Competitive } \\
\text { World }\end{array}$ & $115(75.2)$ & $38(24.8)$ \\
\hline $\begin{array}{l}\text { Make More Competitive Through Internship } \\
\text { Course of Management Field }\end{array}$ & $148(96.7)$ & $5(3.3)$ \\
\hline Requirement of Teacher's Motivation & $148(96.7)$ & $5(3.3)$ \\
\hline Available of Internet Facility & $109(72.2)$ & $44(28.8)$ \\
\hline
\end{tabular}

Sources: Field Survey

Table 1 explains the major determinants and factors related with the BBA programs. Coordination and communication between the administration, teachers' as well as students are important. Study of BBA program makes the students becoming a middle level manager and more competitive in present situation though internship activities but teachers' motivation is important, 96.7 percent are agreed with the statement. On the other side environmental situation hinders the outcomes of this program. Students do not want to involve in the political activities because it is active or student centered program. 
Table 2

Response and Percentage Regarding to becoming a BBA Students

\begin{tabular}{|l|l|l|l|l|}
\hline Factors & $\begin{array}{l}\text { Learn } \\
\text { For }\end{array}$ & Factors & $\begin{array}{l}\text { Effectiveness of } \\
\text { BBA Program }\end{array}$ & $\begin{array}{l}\text { Scope of } \\
\text { BBA }\end{array}$ \\
\hline Business & $31(20.3)$ & A good Manager & $42(27.5)$ & $34(22.2)$ \\
\hline Knowledge only & $5(3.3)$ & Job & $4(2.6)$ & $8(5.2)$ \\
\hline English & $1(0.7)$ & $\begin{array}{l}\text { Business/Entrepre- } \\
\text { neur }\end{array}$ & $38(24.8)$ & $44(28.8)$ \\
\hline $\begin{array}{l}\text { Practical Knowl- } \\
\text { edge }\end{array}$ & $12(7.8)$ & Creative Mind & $47(30.7)$ & $40(26.1)$ \\
\hline All of Above & $103(67.3)$ & Practical & $12(7.8)$ & $15(9.8)$ \\
\hline None of Above & $1(0.7)$ & Others & $10(6.5)$ & $12(7.9)$ \\
\hline Total & 153 & Total & 153 & 153 \\
\hline
\end{tabular}

Sources: Field Survey

Table 2 explains that why students are studying BBA program? Because of this program has distinct nature that students drive in different situation so students are learnt BBA for getting the knowledge about business related matters and problems, subject matters involve in program and practical knowledge which are used by teachers during the teaching and lecturing period.

\section{Table 3}

Responses and Percentage Regarding to Different Pedagogies

\begin{tabular}{|l|l|l|l|l|}
\hline Pedagogies & Highly & Moderate & Less & Total \\
\hline Students' Focus on Pedagogies & $59(38.5)$ & $89(58.2)$ & $5(3.3)$ & 153 \\
\hline Discussion of Topic & $58(37.9)$ & $84(54.9)$ & $10(7.2)$ & 153 \\
\hline Presentation & $43(28.1)$ & $96(62.7)$ & $14(9.2)$ & 153 \\
\hline Class/Homework & $58(39.9)$ & $86(56.2)$ & $9(5.9)$ & 153 \\
\hline Case Study & $46(30.1)$ & $72(47.0)$ & $35(22.9)$ & 153 \\
\hline Focus on Practical/Workshop/Seminar & $38(24.80$ & $91(59.5)$ & $24(15.7)$ & 153 \\
\hline Use of References & $46(30.1$ & $63(41.1)$ & $44(28.8)$ & 153 \\
\hline Internet Access & $52(34)$ & $72(47)$ & $29(19)$ & 153 \\
\hline Practical Knowledge & $64(41.8)$ & $82(53.6)$ & $7(4.6)$ & 153 \\
\hline Use of Pedagogies from Teachers' Side & $5334.4)$ & $86(56.2)$ & $14(9.2)$ & 153 \\
\hline Discussion of Topic & $31(20.3)$ & $96(62.7)$ & $26(17)$ & 153 \\
\hline Presentation & \multicolumn{5}{l|l}{} \\
\hline Class/Homework
\end{tabular}


Janapriya Journal of Interdisciplinary Studies, Vol. 2, No.1 (December 2013)

\begin{tabular}{|l|l|l|l|l|}
\hline Case Study & $54(35.3)$ & $76(49.7)$ & $23(15)$ & 153 \\
\hline Focus on Practical/Workshop/Seminar & $37(24.2)$ & $45(29.4)$ & $71(46.4)$ & 153 \\
\hline Teachers Delivery on Subject Matter & $41(26.8)$ & $98(64.1)$ & $14(9.2)$ & 153 \\
\hline Essential of English Language & $119(77.8)$ & $34(22.2)$ & - & 153 \\
\hline Discipline & $76(49.7)$ & $67(43.8)$ & $10(6.5)$ & 153 \\
\hline
\end{tabular}

Sources: Field Survey

Table 3 shows the different pedagogies are used by teachers' during the teaching period and all the pedagogies are used conditionally in terms of subject and subject matters. These pedagogies are moderately used in the JMC for creation of effectiveness of BBA program but under the one pedagogy- workshop and seminar is not effectively used under the BBA program. It is shown by just 46.4 percent negative response from the students.

\section{Table 4}

Responses and Percentage Regarding to Use of English Language for Effectiveness of BBA

\begin{tabular}{|l|l|l|l|l|l|l|}
\hline Teachers' and Students' by & $100 \%$ & $80 \%$ & $60 \%$ & $40 \%$ & $20 \%$ & Total \\
\hline Use of English language & $16(10.5)$ & $47(30.7)$ & $53(34.6)$ & $26(17)$ & $11(7.2)$ & 153 \\
\hline Speak of English language & $25(16.4)$ & $48(31.4)$ & $53(34.6)$ & $19(12.4)$ & $8(5.2)$ & 153 \\
\hline
\end{tabular}

Sources: Field Survey

English language is essential in the study of BBA program for the students because of it is compulsory to write all the matters and answers in English. So Students feel high degree of necessity of English language by giving moderate or highly essential response. In terms of use and speak of English language either teacher or students are just between 60 to $80 \%$. It covers almost $65 \%$ response from students.

Table 5

Expression by Students on the administration and Program

\begin{tabular}{|l|l|l|}
\hline \multicolumn{1}{|c|}{ Factors } & Response & Percent \\
\hline No Political Activities & 5 & 3.3 \\
\hline Requirement of Guest Lecture & 1 & 0.7 \\
\hline Use of English Language & 1 & 0.7 \\
\hline Expensively Design of Program & 2 & 1.3 \\
\hline No or Nothing to Say & 84 & 54.9 \\
\hline No Extra Curriculum Activities & 3 & 2.0 \\
\hline Requirement of Good Administrative Facilities & 14 & 9.2 \\
\hline
\end{tabular}


Janapriya Journal of Interdisciplinary Studies, Vol. 2, No.1 (December 2013)

\begin{tabular}{|l|l|l|}
\hline Satisfied with Program & 4 & 2.6 \\
\hline Focus on Practical and Presentation & 18 & 11.8 \\
\hline Communication and Coordination & 10 & 6.5 \\
\hline Requirement of Inner Discipline & 1 & 0.7 \\
\hline No Attention by Teacher towards the Students & 1 & 0.7 \\
\hline No Effective Program in JMC & 3 & 2.0 \\
\hline No properly used of Work shop and Seminar & 6 & 3.9 \\
\hline Total & 153 & 100.0 \\
\hline
\end{tabular}

Sources: Field Survey

Among the 153 students, 54.9 percent students do not want to express anything regarding to campus activities.11.8 percent students from the purposive group are expressed to focus on the practical and presentation of subject matters. $9.2 \%$ is wanted to have good administration facilities, $2.6 \%$ students are satisfied with the program in JMC. Likewise, $2 \%$ student is expressed that there is no effective program in JMC.

\section{Conclusion}

The Bachelor of Business Administration programs is of 4-years duration, spread over 8 regular semesters, and consisting of 124-136 credit hours after completing twelve years of higher secondary school certificate or equivalent. This program needs immediate implementation of study matter in the real field. While teaching this program' subject matters, teachers should be up to date and able to use different pedagogy. Therefore teacher is effective or not effective depends upon the students' behavior. This program is design to study under active learning oriented or student centers where students are better prefer to teacher centers. Major pedagogical tools for the study of the BBA program are case study, seminar, discussion, presentation etc. which are moderately used. Students do not like to involve in political matters. Campus environment, coordination and communication are important for the effectiveness of BBA program in JMC. English language is essential to study of this program for both teachers and students. Both the teachers and students are just using 60 to 80 percent event though it is enough to teach and learn this program. This program is especially useful to make students becoming a businessman and entrepreneur than making of middle level manager even though the main objective is to make manager and capable for handling middle level managerial post. Study of this program could not be sure to make a good middle level manager but sure to make a creative mind student. 30.7 percent students believe the situation. Besides that students are not actively participate in the case, discussion, presentation but they are expressing that teachers are not responsible on those mater and interested in the internet facility which are not properly available in during the period. Seminar and workshop are not developed by the campus side even once or twice time in a semester so students view are not good regarding to this. 54.9 percent do not want to express nothing on the side of the campus. Just 2.6 percent are 
satisfied with the college. Even 9.2 percent wants to systematize the administration for delivery of facilities like game, information, extra activities etc. 11.8 students strongly focused on practicability and presentation of subject matter which they expected in joining JMC's BBA program.

\section{Acknowledgement}

This research won't be completed without participation of various persons. The most important gratitude goes to BBA -2067 batch, and Co-coordinator of the BBA-wings of JMC. They helped us to complete the research in time. Beside that respected Pro. Dr. Vikash Kumar KC, for his guidance and continue support to complete this research in time by giving valuable instruction in the field of research is very important. At last but not the least, we are thankful to the students of JMC, our family, friends and other supporter.

\section{References}

Felder R. M. and Brent R. (1996). Navigating the Bumpy Road to Student-Centered published in College Teaching, Department of Chemical Engineering North Carolina State University School of Education East Carolina University, Greenville, USA

Felder R. M. (2011). Hang in There! Dealing with Student Resistance to LearnerCentered Teaching Chemical Engineering Education, 45(2), pp. 131-132 (Spring 2011)

Johnson, D.W. (1991). Cooperative learning: Increasing college faculty instructional productivity. ASHE-ERIC Higher Education Report No. 4. Washington, DC: George Washington University.

Khan M. J. (2012). Curriculum of Business Administration for BBA, BBS, MBA and MS, Higher Secondary Board, Islamabad, Pakistan

Woods, D.R. (1994). Problem-based learning: How to gain the most from PBL. Waterdown, Ontario

http.www.ncate.org.

http://www.hec.gov.pk/InsideHEC/Divisions/AECA/CurriculumRevision/ Documents/BusinessAdmin-2012. 